\title{
UPAYA MENINGKATKAN MOTIVASI DAN PRESTASI BELAJAR SISWA PADA MATERI ALAT OPTIK DENGAN MENGGUNAKAN MEDIA GRAFIS
}

\author{
Tri Erlina Wati ${ }^{1 *}$, Effendi ${ }^{1}$, Siti Anisatur Rofiqoh ${ }^{1}$ \\ ${ }^{1}$ Program Studi Pendidikan Fisika Universitas Nurul Huda \\ "Corresponding author: trierlinawati816@gmail.com
}

Article History:

Received: November 01, 2021

Revised: November 29, 2021

Accepted: Desember 10, 2021

Published: Desember 31, 2021

Keywords: Graphic media, student, motivation and achievement

\begin{abstract}
The purpose of this study was to increase the motivation and learning achievement of eighth-graders at MTs Subulussalam Sriwangi on the concept of optical instruments with the help of graphic media. The type of research used is Classroom Action Research with a qualitative approach. The data in this study were obtained from the results of observations and the results of the final test in each cycle. Based on the results of the study showed that the motivation and learning achievement of students with the help of the use of graphic media has increased. The increase can be seen from the cycle 1 test scores which increased by $72.5 \%$ compared to the pre-study test scores, and the second cycle test scores which increased by $82.5 \%$ compared to the first cycle test scores. Overall, students' learning motivation increased by $10 \%$. The increase in achievement can be seen from the cycle 1 test scores which increased by $73.80 \%$ compared to the preresearch test scores and the second cycle test scores increased by $80.94 \%$ compared to the first cycle test scores. Overall, students' learning achievement increased by $7.14 \%$
\end{abstract}

Abstrak: Tujuan penelitian ini untuk meningkatkan motivasi dan prestasi belajar siswa kelas VIII MTs Subulussalam Sriwangi pada materi alat optik dengan bantuan media grafis. Jenis penelitian ini adalah Penelitian Tindakan Kelas (PTK) dengan menggunakan pendekatan kualitatif. Data pada penelitian ini diperoleh dari hasil observasi dan hasil tes akhir setiap siklus. Berdasarkan hasil penelitian menunjukkan bahwa motivasi dan prestasi belajar siswa dengan bantuan penggunaan media grafis mengalami peningkatan. Peningkatan dapat dilihat dari skor tes siklus 1 meningkat sebesar $72,5 \%$ dibandingkan skor tes pra penelitian dan skor tes siklus 2 meningkat sebesar $82,5 \%$ dibandingkan skor tes siklus 1. Secara keseluruhan motivasi belajar siswa meningkat $10 \%$ dari perbandingan sebelum menggunakan media grafis dan setelah menggunakan media grafis. Peningkatan prestasi dapat dilihat dari skor tes siklus 1 meningkat sebesar $73,80 \%$ dibandingkan skor tes pra penelitian dan skor tes siklus 2 meningkat sebesar $80,94 \%$ dibandingkan skor tes siklus 1. Secara keseluruhan prestasi belajar siswa meningkat $7,14 \%$ dari perbandingan sebelum menggunakan media grafis dan setelah menggunakan media grafis.

\section{PENDAHULUAN}

Belajar merupakan hal yang sangat mendasar yang tidak bisa lepas dari kehidupan semua orang (Hakim et al., 2020). Seiring dengan perkembangan masyarakat dan kebutuhan yang 
meningkat, pemerintah berupaya untuk meningkatkan dunia Pendidikan (Sarwi et al., 2020; Steenkamp et al., 2021). Menurut pengertian secara psikologis, belajar merupakan suatu proses perubahan yaitu perubahan tingkah laku sebagai hasil dari interaksi dengan lingkunganya dalam memenuhi kebutuhan hidupnya (Tati, 2016). Perubahan-perubahan tersebut akan nyata dalam seluruh aspek tingkah laku. Belajar merupakan bagian dari proses pembelajaran, dimana pembelajaran adalah salah satu upaya dalam mengoptimalkan kegiatan belajar siswa dalam rangka untuk mengembangkan potensi yang dimiliki oleh siswa (Ekasari et al., 2020; Purwanto et al., 2021).

Salah satu komponen yang ada dalam proses pembelajaran adalah guru. Secara sederhana guru dapat diartikan sebagai orang yang memberikan ilmu kepada anak didiknya. Guru seorang pendidik profesional dengan tugas utama mendidik, mengajar, mengarahkan, melatih, dan mengevaluasi kegiatan pembelajaran (Adams \& Wieman, 2015).

Selain guru faktor lain yang berpengaruh dalam pembelajaran adalah siswa. Siswa sebagai subjek didik yang harus dikembangkan kemampuannya. Dalam suatu pembelajaran siswa berperan sebagai subjek pembelajaran sedangkan guru adalah sebagai fasilator, motivator, dan pembimbing siswa- siswanya. Setiap siswa memiliki kompetensi yang beragam oleh karena itu guru harus mampu mengembangkan potensi siswa secara optimal (Sastradiharja et al., 2021). Pembelajaran akan berhasil apabila gurunya profesional dan anak didiknya memiliki motivasi belajar yang tinggi.

Upaya untuk mencapai tujuan pembelajaran salah satunya guru harus mampu menggunakan media pembelajaran (Saregar et al., 2019). Penggunaan media pembelajaran dalam proses belajar mengajar dapat membangkitkan keinginan dan minat yang baru, membangkitkan motivasi dan rangsangan kegiatan belajar (Jamil \& Aprilisanda, 2020; Putra \& Wardika, 2021; Salmiati \& Aslinda, 2019; Sari et al., 2021). Selain itu, penggunaan media dalam pembelajaran dapat menyajikan data dengan menarik dan memudahkan penafsiran, melalui meteri media grafis (Halimatus et al., 2019). Media grafis sebagai media yang mengkombinasikan fakta dan gagasan secara jelas dan kuat melalui suatu kombinasi pengungkapan kata - kata dan gambar-gambar (Nana \& Ibrahim, 1989). Media grafis termasuk media visual, sebagaimana media lain media grafis juga mempunyai beberapa fungsi diantaranya menyalurkan pesan dari sumber ke penerima pesan, mengembangkan daya kreatifitas dan imajinasi siswa dan dapat menarik perhatian siswa (Purwani et al., 2019).

Pemilihan media grafis yang tepat harus sesuai dengan materi yang diajarkan. Materi alat optik dengan melengkapi gambar yang diharapkan dapat meningkatkan hasil belajar siswa (Ajizi et al., 2018). Hasil belajar seseorang ditentukan oleh berbagai faktor yang mempengaruhi salah satu faktor yang ada di luar individu adalah tersedianya media pembelajaran yang memberi kemudahan bagi siswa untuk mempelajari materi pembelajaran sehingga menghasilkan prestasi belajar yang lebih baik (Sugiharta, 2019).

Materi alat optik merupakan materi yang kompleks dan cukup sulit, dan membosankan. Hal ini dibuktikan berdasarkan hasil pengamatan yang telah di lakukan terlihat bahwa dari hasil tes ulangan harian semester genap tahun pelajaran 2021 kelas VIII dari 29 siswa terdapat 17 siswa mendapat nilai dibawah KKM dan dari rata-rata prestasi belajar menunjukkan hasil sebesar 6,872. Terlebih lagi cara penyampaian yang digunakan guru kurang menarik Sehingga meyebabkan rendahnya motivasi belajar siswa. 
Penelitian sebelumnya menggunakan media grafis sebagai pengenalan life science pada anak usia dini (Halimatus et al., 2019), menganalisis kemampuan kompetensi IPS (Trisnadewi et al., 2020), dan peningkatan siaga banjir (Purwani et al., 2019). Fokus pada penelitian ini menggunakan variable terikat berupa motivasi dan prestasi belajar siswa.

\section{METODE}

Jenis penelitian ini adalah Penelitian Tindakan Kelas (PTK) dengan menggunakan pendekatan kualitatif. Pada penelitian ini ada 2 siklus yang dilaksanakan, setiap siklus menggunakan 4 tahap yaitu (1) tahap perencanaan, (2) tahap pelaksanaan tindakan, (3) tahap pengamatan (observasi), dan (4) tahap refleksi. Subyek penelitian yang digunakan adalah siswa kelas VIII dengan banyak siswa laki-laki 14 orang dan banyak siswa perempuan 15 orang. Penelitian ini dilaksanakan di MTs Subulussalam Sriwangi pada semester genap tahun pelajaran 2021.

Indikator prestasi belajar yang saya gunakan dalam penelitian ini adalah Kognitif, hal yang diperhatikan dari siswa adalah pengetahuan, pemahaman, penerapan maupun analisisnya. Afektif mencakup sikap yang ditunjukan oleh anak selama masa pembelajaran. Psikomotor.

Sedangkan indikator motivasi ada sepuluh indikator motivasi yaitu: 1) tekun menghadapi tugas, 2) tidak pernah berhenti sebelum selesai, 3) ulet menghadapi kesulitan (tidak lekas putus asa), 4) tidak perlu memerlukan dorongan dari luar untuk berprestasi sebaik mungkin (tidak cepat puas dengan prestasi yang telah dicapainya), 5) menunjukkan minat terhadap bermacammacam masalah, 6) lebih senang bekerja mandiri, 7) Cepat bosan pada tugas-tugas rutin, 8) dapat mempertahankan pendapatnya, 9) tidak mudah melepaskan hal yang diyakininya, dan 10) senang mencari dan memecahkan masalah soalsoal.

Data yang akan diperoleh dari hasil penelitian ini ada 2 yaitu (1) data hasil observasi proses belajar siswa dengan menggunakan media grafis (2) data hasil prestasi dan motivasi belajar siswa setelah penggunaan media grafis. Data hasil observasi diperoleh dari lembar observasi yang dinilai oleh teman sejawat, sedangkan data hasil prestasi belajar siswa diperoleh dari hasil tes akhir setelah siswa menggunakan media grafis. Observasi yang dinilai oleh teman sejawat, sedangkan data hasil prestasi belajar siswa diperoleh dari hasil tes akhir setelah siswa menggunakan media grafis.

Data hasil observasi proses belajar siswa dianalisis dengan analisis deskriptif. Analisis tersebut dikatakan sesuai jika aktivitas belajar siswa mengikuti langkah langkah penggunaan media grafis, sedangkan aktivitas yang belum sesuai akan diperbaiki pada siklus berikutnya. Data hasil prestasi belajar siswa dianalisis dengan cara membandingkan skor yang diperoleh dari tes akhir berbentuk tes tertulis dengan dengan Kriteria Ketuntasan Minimal (KKM) yang ditetapkan sekolah tempat penelitian dilakukan yaitu 65 .

Penelitian ini dilakukan hanya menggunakan 2 siklus karena ukuran berhasil atau tidaknya diukur dari ketercapaian target yang telah ditentukan yang berupa criteria keberhasilan. Data hasil motivasi siswa meningkat 10,33, dan data prestasi belajar siswa meningkat 7,14. Karena PTK bertujuan untuk memperbaiki maka tindakan kedua merupakan perbaikan dari tindakan pertama, begitu seterusnya sampai ditemukan keberhasilan pada peserta didik.

\section{HASIL DAN PEMBAHASAN}

Sebelum melakukan penelitian, peneliti mengadakan pra penelitian yaitu dengan cara memberikan tes pada subyek 
penelitian tentang materi alat optik. Dari hasil tes awal tersebut, ternyata hanya 12 siswa yang berhasil mendapat nilai diatas 65 sedangkan siswa yang lain mendapat nilai dibawah 65. Berdasarkan data tersebut, peneliti merencanakan untuk melakukan penelitian tindakan kelas dengan bantuan media grafis. Penelitian yang akan dilakukan terdiri dari 2 siklus.

Siklus 1

Pada siklus ini ada 4 tahap yang dilakukan oleh peneliti yaitu (1) tahap perencanaan, (2) tahap pelaksanaan tindakan, (3) tahap pengamatan (observasi), dan (4) tahap refleksi.

\section{Perencanaan 1}

Berdasarkan data pra penelitian, peneliti mengadakan beberapa perencanaan dengan tujuan untuk memperbaiki cara belajar siswa khususnya pada materi alat optik. Persiapan awal yang dilakukan peneliti yaitu membuat RPP sesuai dengan langkah-langkah penggunaan media grafis, membuat lembar observasi, serta membuat tes akhir.

\section{Pelaksanaan Tindakan 1}

Tahapan ini merupakan tahapan yang dilakukan langsung oleh peneliti yang bertindak sebagai guru, teman sejawat yang bertindak sebagai observer, dan siswa kelas VIII yang bertindak sebagai subyek penelitian. Peneliti mulai menggunakan media grafis untuk menjelaskan pada siswa tentang materi alat optik. Pada awalnya sebagian besar siswa masih belum menunjukkan ketertarikan terhadap media yang digunakan oleh guru, sehingga pada saat guru memberikan latihan soal dan meminta perwakilan kelompok maju masih banyak yang mengalami kesalahan.

\section{Pengamatan (Observasi) 1}

Tahap observasi ini dilakukan secara bersamaan dengan tahap pelaksanaan tindakan 1 karena pada tahap ini peneliti dibantu oleh observer yaitu teman sejawat untuk mengamati kegiatan siswa dengan menggunakan lembar observasi yang sebelumnya telah dipersiapkan. Hasil dari observasi 1 ditunjukkan pada tabel berikut:

Tabel 1. Hasil Obsevasi Aktivitas Siswa Siklus1

\begin{tabular}{lc}
\hline \multicolumn{1}{c}{ Hal-Hal yang Diamati } & Kategori \\
\hline $\begin{array}{l}\text { Motivasi siswa mengikuti } \\
\text { pembelajaran }\end{array}$ & Baik \\
$\begin{array}{l}\text { Memperhatikan dan } \\
\text { mengikuti penjelasan }\end{array}$ & Cukup \\
materidengan media grafis & \\
Mengerjakan latihan soal & Cukup \\
\hline
\end{tabular}

Berdasarkan hasil observasi di atas, diketahui bahwa siswa yang memperhatikan, mengikuti penjelasan materi dengan media grafis serta mengerjakan latihan soal termasuk kategori cukup sehingga membutuhkan perencanaan untuk siklus II.

Tabel 2. Hasil Obsevasi Aktivitas Siswa Siklus 2

\begin{tabular}{lc}
\hline \multicolumn{1}{c}{ Hal-hal yang Diamati } & Kategori \\
\hline $\begin{array}{l}\text { Motivasi siswa mengikuti } \\
\text { pembelajaran }\end{array}$ & Baik \\
$\begin{array}{l}\text { Memperhatikan dan mengikuti } \\
\text { penjelasan materi dengan media } \\
\text { grafis }\end{array}$ & Baik \\
Mengerjakan latihan soal & Baik \\
\hline
\end{tabular}

Berdasarkan hasil observasi di atas, diketahui bahwa siswa yang pada siklus 2 memperhatikan dan mengikuti penjelasan materi dengan media grafis serta mengerjakan latihan soal dengan kategori baik. Hal ini menunjukkan bahwa aktivitas siswa pada siklus 2 lebih baik dari pada siklus 1 .

\section{Uji Validitas Instrumen Tes}

Uji validitas dilakukan pada siswa yang bukan menjadi sampel penelitian dalam hal ini siswa yang digunakan yaitu siswa dari sekolah MTs Subulussalam Sriwangi tepatnya dikelas VIII yang berjumlah 29.

Tabel 3. Hasil perhitungan Validitas Instrumen Siklus I dan II

\begin{tabular}{lll}
\hline Kriteria & Nomor Butir Soal & Jumlah \\
\hline Valid & $1,2,3,5,6,7,9,10,11,12,13$, & 20 \\
& $15,17,18,19,20,21,23,24,25$ & \\
Tidak & $4,8,14,16,22$ & 5 \\
valid & & \\
\hline
\end{tabular}


Berdasarkan tabel 3 diatas menunjukan dari 25 nomor soal yang diujikan terdapat 5 soal yang tidak valid yaitu soal no 4, 8, 14, 16 dan 22 karena nilai $r_{\text {hitung }}<r_{\text {tabel }}$.

\section{Uji Reliabilitas Instrumen Tes}

Suatu tes dapat dikatakan mempunyai taraf kepercayaan yang tinggi jika tes tersebut dapat memberikan hasil yang tetap. Apabila datanya memang benar sesuai dengan kenyataan, maka berapa kalipun diambil akan tetap sama reliabilitas menunjuk pada tingkat keterandalan sesuatu. Datanya diperoleh pada tabel 4.

Tabel 4. Reliablitas Instrumen Tes

\begin{tabular}{lccc}
\hline $\begin{array}{c}\text { Soal } \\
\text { Materi }\end{array}$ & $\boldsymbol{r}_{11}$ & $\begin{array}{c}\text { Nilai } \\
\text { pembanding }\end{array}$ & Keputusan \\
\hline Alat Optik & 0,85 & 0,70 & Reliabel \\
Alat Optik & 0,89 & 0,70 & Reliabel \\
\hline
\end{tabular}

Berdasarkan tabel 4 diatas hasil dari uji reliabilitas dapat diketahui nilai $r_{11}$ pada siklus I yaitu 0,88 dan pada siklus II yaitu 0,89 yang berarti semua soal reliabel, karena $r_{\text {hitung }} \geq r_{\text {tabel }}$ pada siklus I yaitu 0,88 dan pada siklus II yaitu 0,89 lebih dari 0,70 maka instrumen penelitian tersebut dapat digunakan dalam pengumpulan data.

\section{Uji Tingkatan Kesukaran Instrumen Tes}

Tingkat kesukaran tes adalah pernyataan tentang seberapa mudah atau seberapa sukar sebuah butir tes itu bagi testee atau siswa terkait. Jumlah 20 soal instrumen tes, 3 soal memiliki taraf kesukaran mudah yaitu $3,15,18,15$ soal memiliki taraf sedang yaitu 1, 2, 5, 6, 7, 9, 10, 11, 12 .

\section{Uji Daya Pembeda Instrumen Tes}

Menurut Djamarah (2017: 57) daya pembeda soal adalah kemampuan suatu soal untuk membedakan siswa yang berkemampuan tinggi dengan siswa yang berkemampuan rendah 2 soal dengan daya pembeda sangat baik (indeks diskriminasi $0,71-1,00$ ) yaitu nomor
10,12. Terdapat 14 soal dengan daya pembeda baik (indeks diskriminasi 0,41 0,70 ) yaitu nomor $1,2,5,6,7,9,13,15$, $19,20,21,23,24$ dan 25. Terdapat 4 soal dengan daya cukup (indeks diskriminasi $0,21-0,40$ ) nomor $3,11,17,18$.

\section{MOTIVASI BELAJAR}

Dari hasil perhitungan motivasi belajar diperoleh hasil analisis motivasi belajar siswa dari siklus I ke siklus II ditunjukkan tabel 5.

Tabel 5. Motivasi belajar siswa

\begin{tabular}{lccccc}
\hline \multicolumn{5}{c}{ Target } & \multicolumn{3}{c}{ Pencapaian } \\
\multicolumn{1}{c}{ Uraian } & $\begin{array}{c}\text { Sikl } \\
\text { us }\end{array}$ & $\begin{array}{c}\text { Sikl } \\
\text { us }\end{array}$ & $\begin{array}{c}\text { Sikl } \\
\text { us }\end{array}$ & $\begin{array}{c}\text { Sikl } \\
\text { us }\end{array}$ & $\begin{array}{c}\text { Peningka } \\
\text { tan }\end{array}$ \\
& I & II & I & II & \\
\hline $\begin{array}{l}\text { Nilai rata- } \\
\text { rata }\end{array}$ & 70 & 75 & 73,7 & 84 & 10,3 \\
$\begin{array}{l}\text { Jumlah } \\
\text { item }\end{array}$ & & & & & \\
$\begin{array}{l}\text { dengan } \\
\text { nilai } \geq\end{array}$ & - & - & 16 & 24 & 8 \\
$\begin{array}{l}\bar{X}) \\
\text { Jumlah }\end{array}$ & & & & & \\
item \\
dengan
\end{tabular}

Tabel 5 menunjukkan hasil motivasi belajar siswa dengan menggunakan media grafis pada siklus I nilai rata-rata sebesar 73,7, Nilai rata-rata meningkat pada siklus II menjadi 84 dengan peningkatan 10,3 dari target yang telah ditentukan sebesar 70 pada siklus I dan 75 pada siklus II.

\section{PRESTASI BELAJAR}

Kemampuan kognitif siswa siklus I dan siklus II ditunjukkan pada tabel 6 berikut:

Tabel 6. Perbandingan Hasil Prestasi Belajar

\begin{tabular}{cccccc}
\multicolumn{9}{c}{ Target } & \multicolumn{2}{c}{ Pencapaian } & Peni \\
Uraian & Sikl & Sikl & Sikl & Sikl & ngka \\
& us & us & us & us & tan \\
& I & II & I & II & \\
\hline $\begin{array}{c}\text { Nilai rata- } \\
\text { rata }\end{array}$ & 70 & 75 & 73,8 & 80,9 & 7.14
\end{tabular}




\begin{tabular}{|c|c|c|c|c|c|}
\hline \multirow[b]{2}{*}{ Uraian } & \multicolumn{2}{|c|}{ Target } & \multicolumn{2}{|c|}{ Pencapaian } & \multirow[b]{2}{*}{$\begin{array}{c}\text { Peni } \\
\text { ngka } \\
\tan \end{array}$} \\
\hline & $\begin{array}{c}\text { Sikl } \\
\text { us } \\
\text { I }\end{array}$ & $\begin{array}{c}\text { Sikl } \\
\text { us } \\
\text { II }\end{array}$ & $\begin{array}{c}\text { Sikl } \\
\text { us } \\
\text { I }\end{array}$ & $\begin{array}{c}\text { Sikl } \\
\text { us } \\
\text { II }\end{array}$ & \\
\hline $\begin{array}{l}\text { Jumlah } \\
\text { item } \\
\text { dengan } \\
\text { nilai } \geq \\
(\bar{X})\end{array}$ & - & - & 14 & 21 & 7 \\
\hline
\end{tabular}

Tabel 6 menunjukkan hasil tes kemampuan kognitif siswa nilai rata-rata kelas mengalami peningkatan dari 73,80 pada siklus I menjadi 80,94 pada siklus II dengan peningkatan 7,14. Hasil ulangan I yang dilakukan pada akhir pembelajaran siklus I menunjukkan bahwa siswa yang mendapat nilai dibawah 73,80 atau dibawah rata-rata kelas sebanyak 17 siswa dan 7 siswa mendapat nilai diatas rata-rata kelas. Hasil ulangan II yang dilakukan pada akhir pembelajaran siklus II menunjukkan bahwa siswa yang mendapat nilai dibawah 80,94 atau dibawah rata-rata kelas sebanyak 10 siswa dan 19 siswa mendapat nilai diatas ratarata kelas.

Temuan penelitian ini sesuai dengan peneliti sebelumnya bahwa media grafis dapat mempermudah dalam memahami materi. Temuan lain penelitian ini bahwa media grafis dapat meningkatkan motivasi siswa.

\section{KESIMPULAN}

Berdasarkan analisis data dan hasil penelitian tentang upaya meningkatkan motivasi dan prestasi belajar siswa pada materi alat optik di kelas VIII MTs Subulussalam dapat disimpulkan motivasi dan prestasi belajar sebelum menggunakan media grafis pada materi alat optik sangat rendah dan prestasi belajar yang didapatkan belum mencapai nilai KKM yang telah ditetapkan dan dari rata-rata prestasi belajar menunjukkan hasil sebesar 6,8.

Motivasi dan prestasi belajar sesudah menggunakan media grafis pada materi alat optik ada peningkatan dan prestasi yang didapatkan sudah mencapai nilai
KKM yang telah ditetapkan dan dari ratarata prestasi belajar menunjukkan hasil sebesar 80,94.

\section{SARAN}

Bagi Peneliti selanjutnya, diharapkan dapat memaparkan lebih luas lagi konsep-konsep fisika. Pada penelitian ini hanya terfokus pada materi alat optic.

Bagi Peneliti selanjutnya juga diharapkan lebih baik lagi secara keseluruhan.

\section{DAFTAR PUSTAKA}

Adams, W. K., \& Wieman, C. E. (2015). Analyzing the many skills involved in solving complex physics problems. American Journal of Physics, 83(5), 459-467. https://doi.org/10.1119/1.4913923

Ajizi, I., Pursitasari, I. D., \& Ardianto, D. (2018). Pembelajaran Inkuiri Berbasis Multimedia Interaktif pada Materi Optik untuk Meningkatkan Penguasaan Konsep dan Sikap Belajar Siswa. Journal of Science Education And Practice, 2(1), 4457.

Ekasari, F., Effendi, E., \& Anisatur Rofiqah, S. (2020). Pengaruh Pendekatan Accelerated Learning Melalui Metode Whole Brain Teaching Terhadap Hasil Belajar Fisika Smp Materi Usaha Dan Pesawat Sederhana. U-Teach: Journal Education of Young Physics Teacher, 1(2), 47-55. https://doi.org/10.30599/uteach.v1i2. 29

Hakim, S., Effendi, E., \& Widayanti, W. (2020). Perbandingan Model Group Investigation dan Number Head Together: Analisis terhadap Hasil Belajar. U-Teach: Journal Education of Young Physics Teacher, 1(1), 1117. https://doi.org/10.30599/uteach.v1i1. 18 
Halimatus, H., Fridani, L., \& Meilani, S. M. (2019). Pengembangan Media Grafis untuk Pengenalan Life Science pada Anak Usia Dini. Jurnal Obsesi: Jurnal Pendidikan Anak Usia Dini, 4(1), 395-405. https://doi.org/10.31004/obsesi.v4i1. 318

Jamil, S. H., \& Aprilisanda, I. D. (2020). Pengaruh Pembelajaran Daring Terhadap Minat Belajar Mahasiswa Pada Masa Pandemik Covid-19. Behavioral Accounting Journal, 3(1), 37-46. https://doi.org/10.33005/baj.v3i1.57

Nana, S., \& Ibrahim. (1989). Penilaian dan Penelitian Pendidikan. Mandar Maju.

Purwani, A., Fridani, L., \& Fahrurrozi, F. (2019). Pengembangan Media Grafis untuk Meningkatkan Siaga Bencana Banjir. Jurnal Obsesi: Jurnal Pendidikan Anak Usia Dini, 3(1), 55-67.

https://doi.org/10.31004/obsesi.v3i1. 142

Purwanto, G. D., Ulyan, M., \& Basit, A. (2021). Implementation of Industrial Based Islamic Education Management in Pesantren Darussalam Al-Fatah Cilacap. Budapest International Research and Critics in Linguistics and Education (BirLE) Journal, 4(1), 630-641.

Putra, I. P. S. A., \& Wardika, I. W. G. (2021). Penggunaan Aplikasi Google Classroom dalam Upaya Meningkatkan Motivasi Belajar Matematika Mahasiswa. Jurnal Emasains: Jurnal Edukasi Matematika Dan Sains, 10(1), 111120.

Salmiati, S., \& Aslinda, A. (2019). Urgensi Perpustakaan dalam Meningkatkan Minat Baca Peserta Didik tentang Materi Pendidikan Agama Islam. Jurnal Al-Ibrah, 8(1).
Saregar, A., Hadiati, E., Syafe'i, I., Septiani, R., \& Widayanti, W. (2019). Developing Web-Enhanced Course in Basic Electronic Course. Journal of Physics: Conference Series, 1155(1). https://doi.org/10.1088/17426596/1155/1/012094

Sari, A. C., Kartikawati, S., \& Prastyaningrum, I. (2021). Pengaruh Model pembelajaran Gallery Walk Melalui Pemanfaatan Media PhET Terhadap Kemampuan Berpikir Kritis Siswa. Jupiter (Jurnal Pendidikan Teknik Elektro), 6(1), 16. http://ejournal.unipma.ac.id/index.php/JUPI TER/article/view/8921

Sarwi, S., Yusnitasari, A., \& Isnaeni, W. (2020). Concept Mastery of Ethnoscience-Based Integrated Science and Elementary Students' Life Skills Using Guided Inquiry. Advances in Social Science, Education and Humanities Research, 443(Iset 2019), 517-522.

Sastradiharja, H. E. J., Zuhri, S., \& Rojak. (2021). Pengaruh Media Sosial dan Lingkungan Sosial Sekolah Terhadap Perilaku Religius Siswa. Wawasan: Jurnal Kediklatan Balai Diklat Keagamaan Jakarta, 2(1), 74-91.

Steenkamp, C. M., Rootman-le Grange, I., \& Müller-Nedebock, K. K. (2021). Analysing assessments in introductory physics using semantic gravity: refocussing on core concepts and context-dependence. Teaching in Higher Education, 26(6), 871-886. https://doi.org/10.1080/13562517.20 19.1692335

Sugiharta, S. (2019). Upaya Meningkatkan Prestasi Belajar Biologi dengan Strategi Pembelajaran Ekspositori. Jurnal Inovasi Pembelajaran, 5(2), 1-6. 
Tati, N. (2016). Pembelajaran Psikologi Pendidikan Di Madrasah Ibtidaiyah. Al Ibtida, 3(1), 74-92.

Trisnadewi, N. K., Putra, M., \& Ardana, I. K. (2020). Model Advance Organizer Berbantuan Media Grafis Berpengaruh Terhadap Kompetensi Pengetahuan IPS. Mimbar Ilmu, 25(2), 162-173. https://doi.org/10.23887/mi.v25i2.25 152 